\title{
免疫グロブリンスーパーファミリー
}

井上 修*

\section{Immunoglobulin superfamily}

Osamu INOUE

要約：Immunoglobulin-superfamily (Ig-SF) は原始的な生物にも存在する膜蛋 白である. 生命の進化に合わせ機能が継ぎ足され，現在は数千種類の多様性 を持つ一大ファミリーとなった，その一部は，血栓止血の中心的な役割を担 う血小板でも, 膜蛋白として利用されている. 傷からの出血を早く止めるこ とが生存競争の重要課題であった哺乳類では, 血小板膜上に Ig-SF を持つこ とが迅速な血栓止血に決定的なアドバンテージをもたらし, 現在の繁栄の一 因になったと想像される。本稿では血小板膜上の Ig-SFに焦点をあて, その 役割について紹介したい.

Key words: platelets, Ig-SF, Fc, ITAM, ITIM

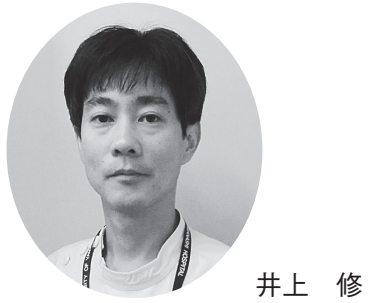

1996年3月 山梨医科大学医学部 卒業

同年5月 NTT関東逓信病院内科 系レジデント（２001年3月）

2001年4月 University of Oxford, academic visitor

同年10月 同D.Philos course ( 2005年3月卒業)

2003年11月 山梨大学附属病院 検査部 医員

2005年4月 同助教

2010年4月 山梨大学大学院医学 工学総合研究部臨床検査医学 助教

2013年4月 山梨大学医学部附属 病院安全管理部感染制御室 特任准教授
血小板は骨髄巨核球から生成される無核の巨核球 細胞質フラグメントである。ヒト血小板の直径は約 $3 \mu \mathrm{m}$, 末梢血流中での寿命は 8 日前後である. 細胞 質には分泌顆粒である $\alpha$ 顆粒が数十個と濃染顆粒 が数個存在し，前者には fibrinogen や von Willebrand factor (VWF) 等の蛋白質性の，後者には adenosine diphosphate (ADP) や serotonin よ゙非蛋白質性の生 理活性物質が貯蔵されている。外傷などにより出血 が始まると，血小板は直ちに血管壁傷害部位に接着 し，活性化される。活性化した血小板は分泌顆粒を 放出，放出された生理活性物質が周囲の血小板をさ らに活性化することで凝集塊を形成し，速やかに血 栓止血を完了する。このように血小板がその主たる 役割を演じるためには，血小板表面に外部からの刺 激を血小板内部に伝達し“血小板を活性化する”ため のアンテナが必要となる，免疫グロブリンスーパー ファミリー(immunoglobulin-superfamily; Ig-SF)はこ のアンテナの一群として機能している.

\footnotetext{
*責任者連絡先：

山梨大学医学部附属病院安全管理部 感染制御室

干 409-3898 山梨県中央市下河東 1110

Tel: 055-273-1111（内線 6783）, Fax: 055-273-6713

E-mail: oinoue@yamanashi.ac.jp
}

\section{Ig-SF とは?}

細胞表面に発現する様々な膜蛋白のうち，分子内 に免疫グロブリン $(\mathrm{Ig})$ または免疫グロブリン様ドメ イン $(\mathrm{Ig}$ ドメイン)を持つ蛋白を総じて Ig-SF と総称 する。年の基本型である免疫グロブリン $(\mathrm{Ig})$ は重鎖 (H 鎖) 2 本と軽鎖 $(\mathrm{L}$ 鎖) 2 本が $\mathrm{Y}$ 字型に組み合わさっ た $\mathrm{Y}$ 字型 4 本鎖構造をとっている. H 鎖には $\gamma$ 鎖, $\mu$ 鎖， $\alpha$ 鎖， $\delta$ 鎖， $\varepsilon$ 鎖の 5 種類， $\mathrm{L}$ 鎖には $\lambda$ 鎖と $\kappa$ 鎖の 2 種類があり, これらの組み合わせにより $\operatorname{IgM}$ や IgG 等の Igアイソタイプが決定される。また, $\mathrm{Y}$ 字の 2 本の腕を $\mathrm{Fab}$ 部分, 軸の部分を $\mathrm{Fc}$ 部分と 呼ぶ. Fab 部分の先端にある抗原認識部位を可変領 域 ( $\mathrm{V}$ 領域), Fab の残りの部分と Fc 部分をあわせ て定常領域 (C 領域) と呼ぶ. 一方, Ig-SF の Ig ドメ インでも， $\mathrm{V}$ 領域に類似する構造を持つものを $\mathrm{V}$ セット, $\mathrm{C}$ 領域に類似する構造を持つものを Cセッ 卜と呼ぶ. $\mathrm{C}$ 領域や $\mathrm{C}$ セットは, それぞれ $\mathrm{V}$ 領 域に類似の配列を持つ $\mathrm{C} 2$ と, 類似しない $\mathrm{C} 1$ がある.

Ig-SF は原始的な鞭毛虫の段階で既に 6 個認めら れることから，生物が発生した初期段階から存在し ていたと考えられる。その後も Ig 蛋白をコードす る遺伝子と他の蛋白遺伝子の間で重複や混成といっ 
た継ぎはぎ(進化)がくりかえされ，ナメクジウオの 段階で 718 種類, ヒトに至っては 3400 種類以上も の多様な Ig-SF 蛋白が存在するまでに多様化した

Ig-SF に属する膜蛋白の多くは特定の構造を認識 する受容体としてカルシウムイオン非依存性にリ ガンドと同種親和性結合または異種親和性結合し, 細胞内にシグナルを惹起し, 免疫防御機構以外の役 割も演じている。これらの受容体には, 細胞内ドメ インに活性化シグナルを惹起する ITAM motif(immunoreceptor tyrosin-based activation motif)を持つも のと抑制性シグナルを惹起する ITIM motif(immunoreceptor tyrosin-based inhibition motif)を持つものあ る. ITAM motif は Y-x-x-L 配 列 ( $\mathrm{Y}$ : tyrosine, L : leucine, $\mathrm{x}$ : 任意)を持ち, 通常 $2 つ, 6 \sim 8$ アミノ酸 を挟んで存在する。これら ITAM motif の Y が 2 箇 所リン酸化されると, Syk(血小板)やZAP-70(T 細 胞) などリン酸化チロシンに結合する SH2 ドメイン を2つ持つキナーゼが結合し, 活性化シグナルが惹 起される ${ }^{1)}$. ITIM motifは (L/I/V/S)-x-Y-x-X-(L/V) (L: leucine, $\mathrm{I}:$ isoleucine, $\mathrm{V}:$ valine, $\mathrm{S}:$ serine, $\mathrm{Y}:$ tyrosine, $\mathrm{x}$ : 任意)を持ち, やはり通常は2 2 存在する. $\mathrm{Y}$ がリン酸化されることで $\mathrm{SH} 2$ ドメインを 2 つ持 つフォスファターゼが結合し，抑制性のシグナルを 惹起する。このように Ig-SF には細胞内シグナルの 活性化と抑制化を調節する重要な役割を演じるもの もある22.

Ig-SF に属する膜蛋白は血小板膜上に複数発現し ており, 細胞内シグナルを惹起して血小板機能の調 節に関わるものが知られている(図 1).

\section{GPVI/FcR $\gamma$-chain}

GlycoproteinVI (GPVI) は Ig-SF に属しNK 細胞に 発現する natural killer receptors との相同性が高い I 型膜蛋白である ${ }^{3)}$. 分子量は約 $62 \mathrm{kDa}$, 血小板膜上 には 1 血小板あたり 1500３000 copy 発現してい $ろ^{4,5)}$. GPVI は分子量約 $12 \mathrm{kDa}$ の Fc receptor gamma-chain $(\mathrm{FcR} \gamma)$ と連関した形で血小板膜上に共発現 しており，FcR $\gamma$ を遺伝子改变により欠損させたマ ウスには GPVIの発現も認められなくなる ${ }^{6}$. 一方 でGPVIを欠損させても FcR

GPVI は出血時間が軽度延長しコラーゲン刺激に
よる血小板凝集を欠損した日本人症例の研究により 同定されたコラーゲン受容体である ${ }^{8)}$. この症例で は，健常人の血小板 lysateを電気泳動した際に $62 \mathrm{kDa}$ 付近に泳動される GPVI を特異的に認識する 抗体が血液中に存在しており，しかし患者血小板に はGPVIの発現が認められなかった。その後も数名 の GPVI 欠損症例が報告され，これらの症例検討か ら GPVIがコラーゲン受容体として機能しているこ とが裏付けられた

GPVI の細胞外ドメインには 2 つの C2 セット (IgC2-like domain)が存在する。 Ig-C2-like domain には 蛋白の折りたたみ構造に重要な N-glycosilation site が 1 箇所あり, 球状構造をとっている. Ig-C2-like domainは先端から順にD1, D2 ドメインと呼ばれる. D1 ドメインがコラーゲンへの結合に重要と考えら れている ${ }^{13,14)}$ ，その細胞膜側は O-glycosilation site を 多数持つ mucin-like domain となっている. 細胞膜貫 通部分に存在するアルギニン残基は，GPVI と FcR $\gamma$ の連関に重要な役割を担っている. 細胞内ドメイン にはプロリンに富む領域 (proline-rich region)が存在 し, この部位には活性化シグナル分子の最上流にあ たる Src family kinase が自身の SH3 ドメインを介し て結合する。 GPVIは III 型コラーゲン分子の $\alpha 1$ (III) 線維上の Gly-Pro-HyP (G-P-O) 配列を認識し, 血小 板活性化シグナルを惹起することが報告されてい る.コラーゲン 1 分子中には G-P-O 配列が約 10\% の頻度, 約 30 個, 含まれている. 結晶解析によると, GPVI は血小板膜上でD2 を介して2 分子が近接し て配置し，対になった $2 つ の \mathrm{D} 1$ が螺旋状のコラー ゲン線維の 4 分子分, 約 55A 離れた位置の G-P-O 配列を認識しているようである15)、コラーゲンと結 合した GPVI は, 血小板内に活性化シグナルを惹起 する。この際に重要な役割を演じるのが GPVI と連 関して発現する FcR $\gamma$ である。（FcR $\gamma$ は F c 受容体の $\gamma$ 鎖のみからなる膜蛋白で F c $\gamma$ 受容体とは異なる分

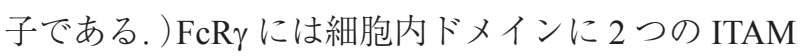
motif が存在する. GPVIに結合した Src family kinase の Fyn や Lyn はこの ITAM motif の Yをリン酸 化する。するとリン酸化チロシンに結合する SH2 domain 2 つ持つSyk が ITAM motif へ結合する。 Syk は自分で，あるいは隣の GPVI/FcR $\gamma$ の ITAM に 結合したSyk と互いにY525/526 部位にあるチロ 


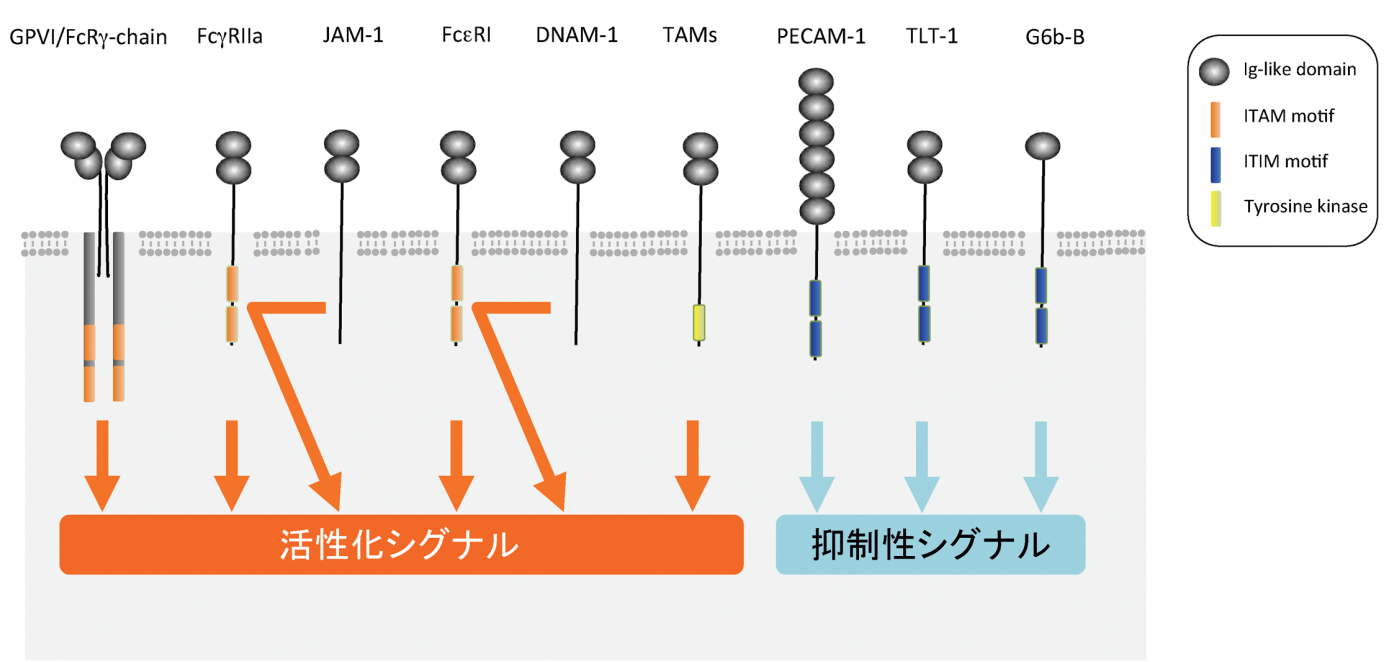

図 1 血小板膜上に発現する主な immunoglobulin-superfamily 血小板膜上の Ig-SF は ITAM motif を持つもの, ITIM motif を持つもの，自身ではこれらの motif を持 たないが，他の膜蛋白の ITAM/ITIM motif を利用してシグナルを惹起するのもなど，多様な仕組みで シグナルを惹起する膜蛋白が存在する。生理的な役割が解明されていない膜蛋白も多い.

シン残基をリン酸化し， kinase 活性を持つ。一連の メカニズムは，同じ Ig-SF の T-cell 受容体における ZAP-70を介した信号伝達系と類似している ${ }^{16)}$ 。 以 降活性化カスケードが作動し, LAT, SLP-76, SLAP-130, Gads といったアダプター蛋白のチロ シンリン酸化を経てシグナル伝達に必要な分子が細 胞膜近傍へ集められた後, Tec family kinae の Btk/ Tecによる phopholipase C $\gamma 2$ (PLC $\gamma 2)$ の活性化へと繋 がる ${ }^{17)}$. PLC 2 は血小板膜の phospahtydil inositol 2-phosphate(PIP2)を水解し, イノシトール 3 リン酸 （IP3）とジアシルグリセロール (DG)を生成させ, IP3 は細胞内カルシウムストア上の IP3 受容体を介 して細胞内カルシウムを動員し, DG は PKCの活 性化を引き起こす。 GPVI が活性化するシグナル分 子はさらにRAPや PI $3 \mathrm{~K}$ 等の活性化も惹起し, 最 終的に細胞骨格改の再構成による変形，顆粒内の七 ロトニンや ADP, フィブリノーゲンといった生理 活性物質の放出, 細胞膜からのアラキドン酸遊離と トロンボキサン A2 の合成および放出，それぞれの 活性物質に対応する血小板膜上の活性化受容体を介 した血小板の更なる活性化等 ${ }^{18)}$ が連続して起こり, インテグリン $\alpha \operatorname{IIb} \beta 3$ の活性化による血小板凝集反 応やインテグリン $\alpha 2 \beta 1$ を介したコラーゲンへの血 小板接着や血小板血栓の形成など，血管壁損傷時の
血栓止血帰転にイメージされる種々の血小板活性化 反応の中心的な役割を演じる。

\section{Fe $\gamma \mathrm{RIIa}(\mathrm{CD} 32)$}

Fc $\gamma$ RIIa は $\operatorname{IgG}$ の Fc 部分を認識する低親和性 Fc 受容体で，血小板と白血球に発現する ${ }^{19)}$ 。分子量は 約 $42 \mathrm{kDa} ， 1$ 回膜貫通型の膜蛋白で，血小板膜上に は 1 血小板あたり 2000〜3000 copy 発現している ${ }^{20)}$. $\mathrm{Fc}$ 受容体の一鎖である FcR $\gamma$ とは異なり, Ig の Fc 部分を認識する受容体そのものである。Fc $\gamma$ RIIaは GPVI 同様に2つの C2 セット (Ig-C2-like domain) が 細胞外ドメインに認められる。さらに自身の細胞内 ドメインに2つの ITAM motifを持っている。した がって，惹起される活性化シグナルは，主にGPVI と同様に Src family kinase-Syk-PLC $\gamma 2$ の組み合わせ となる。

Fc $\gamma$ RIIa は heparin-induced thrombocytopenia (HIT) の病態を引き起す責任受容体として知られてい

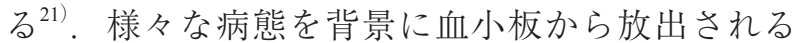
platelet factor $4(\mathrm{PF} 4)$ と治療目的で患者に投与された ヘパリンが結合すると，PF4の構造が変化し新たな 抗原部位が表出され，この部位をリガンドとする特 異的 $\operatorname{IgG}$ 抗体(抗 PF4/ヘパリン抗体) も産生される. 
それらの抗体の中で血小板 F $c \gamma$ RIIaを介して血小板 を活性化する作用のある特殊な抗体が産生された場 合，これを HIT 抗体と呼ぶ. HIT 抗体の Fc 部分は FcyRIIaを介して血小板を活性化する. 活性化血小 板からはマイクロパーティクルが放出され，マイク ロパーティクル上の組織因子によりトロンビンが過 剰に産生される。その結果, 血小板活性化(凝集)と トロンビン産生過多(凝固系立進)による重篤な血小 板減少症や血栓塞栓症が引き起こされると考えられ る。一方, Fc rRIIaの生体内での生理的役割につい ては，血清中の $\operatorname{IgG}$ をキッチして血小板 $\alpha$ 顆粒 内へ小胞輸送する釣り竿としての役割に加え, 活性 化受容体としての役割が報告されている，インテグ リン $\alpha \operatorname{IIb} \beta 3$ がそのリガンドであるフィブリノー ゲンに結合すると Fc $\gamma$ RIIa の ITAM 部位にあるチロ シン残基や Syk, PLC $\gamma 2$ 等の活性化シグナル分子が チロシンリン酸化され, これらのチロシンリン酸化 がFc $\gamma$ RIIa 阻害抗体で強く抑制されること, Fc $\gamma$ RIIa を発現していない血小板では fibrinogen 上での血小 板伸展が抑制されること等である ${ }^{22,23)}$ 。さらに動脈 を傷害して血栓形成の差異を見るin vivo 血栓モデ ルでも, Fc rRIIaを発現させたマウスでは通常のマ ウスと比較して血栓形成が促進されることも報告さ れている ${ }^{24)}$. Fc $\gamma$ RIIaは，インテグリン $\alpha \operatorname{IIb} \beta 3$ から の outside-in シグナルを増強する役割を担っている のだろうと推測される。

\section{Junctional adhesion molecule (JAM, JAM-1, JAM-A, The F11 receptor)}

血小板を活性化させる抗ヒト血小板膜蛋白モノク ローナル抗体F11の認識部位として発見された。 JAM は 1 回膜貫通型の受容体で, 上皮細胞や血管 内皮細胞間のタイトジャンクション形成に関わる膜 蛋白として知られるが, 血小板や赤血球, リンパ球 にも発現している。細胞外ドメインに2つのC2セッ ト (Ig-C2-like domain) が存在するが, 細胞内ドメ インにはITAM motif は存在しない25). 血小板膜上 の JAM は $29 \mathrm{kDa} の コ ア$ 部分に糖鎖が付加され, $32 \mathrm{kDa}$ の JAM-1 と $35 \mathrm{kDa}$ の JAM-2 として発現し ている ${ }^{26)}$.

JAM に結合したF11 は，そのFc 部分が Fc $\gamma$ RIIa
に結合することで血小板凝集を惹起する．Fab 部分 のみの F11-Fab フラグメントでは血小板凝集は惹起 されない. しかし固相化したF11 へ接着した血小板 が示すスプレッディングは Fc $\gamma$ RIIa を抗体(IV.3)で 阻害しても抑制されないことから，Fc $\gamma$ RIIaを介さ ない血小板活性化経路が存在する可能性も示唆され ている. ${ }^{25)}$

血小板膜上の JAM がどのような生理的役割を 担っているかは不明の点が多いが, 原因不明の血小 板減少を来した患者血清中にJAMに対する自己抗 体が検出された事例も報告されており ${ }^{25)}$ ，JAM は HIT と同様のメカニズムで血小板を過剩に活性化 し, 血栓症や血小板減少症を引き起こす可能性があ る受容体と認識する必要がある。

\section{PECAM-1 (CD31)}

Platelet-endothelial cell adhesion molecule-1 (PECAM-1) は血小板, 血管内皮細胞, 好中球などに発 現しており，隣り合った細胞の PECAM-1 と同種親 和性に結合する。血小板では活性化抑制シグナルを 惹起する受容体で, 分子量は約 $130 \mathrm{kDa}, 1$ 回膜貫 通型の膜蛋白で, 血小板膜上には 1 血小板あたり 8000〜10000 copy 程度発現している ${ }^{27,28)}$. PECAM-1 は細胞外ドメインに 6 つの C2 セット (Ig-C2-like domain) が存在するが，その中でも 1 番先端の Ig-C2like domain が同種親和性結合に重要と考えられ る ${ }^{28)}$. 細胞内ドメインには 2 つ ITIM motif が存在 する。リガンド結合により Src kinase が C 末側の Y をリン酸化すると, 次いで $\mathrm{N}$ 末側の Y が Csk や Btk といった non-receptor tyrosine kinases(NRTKs)に よりリン酸化される。こうして ITIM motifの $2 つ$ の Y がリン酸化されると, SH2 ドメインを 2 つ持 つフォスファターゼの SHP-2 や SHP-1 が結合す る ${ }^{29)}$. SHP は GPVI/FcR $\gamma$ からの Src family kinase に よる活性化シグナルと, 同じく Srcを介した GPIb$\mathrm{IX}-\mathrm{V}$ 複合体からの活性化シグナルを脱リン酸化に より抑制性に調節する ${ }^{30-32)}$. ITIMのチロシンリン 酸化を担う NRTK は ITAM シグナルで活性化され る phosphatidylinositol 3-kinase(PI3K)の下流で活性 化されるため, PECAM-1 は ITAM からの血小板活 性化シグナルを減速するブレーキ役として機能して 
いると思われる ${ }^{33)}$ ．実際，PECAM-1 欠損マウスで はコラーゲン刺激での血小板凝集や顆粒放出反応が 六進し, in vivo 血栓モデルでも血管傷害部位での血 栓形成が PECAM-1 欠損マウスで充進し閉塞時間も 短縮するなど，PECAM-1 からの ITIM シグナルが 欠損した状態では GPVI/FcR $\gamma$ を介したITAM シグ ナルが立進することが報告されている ${ }^{31,34,35)}$ 。一方 で, PECAM-1 欠損マウス血小板では血餅退縮が減 弱することなどから，PECAM-1 がインテグリン $\alpha \operatorname{IIb} \beta 3$ からの outside-in シグナルを促進するとの報 告も為されている ${ }^{36)}$. PECAM-1 は血小板機能の抑 制を司る Ig-SF と思われるが，血栓止血メカニズム におけるネットの役割は依然として不明である。

\section{6. その他}

\section{Fec RI}

$\alpha$ 鎖 1 本, $\beta$ 鎖 1 本, $\gamma$ 鎖 2 本からなる高親和性

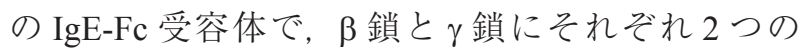
ITAM motif を持つ。 T 細胞に加元，血小板・巨核球 系での発現が報告されている ${ }^{37)}$. RANTES の放出を 惹起しアレルギー反応の遷延に関与する可能性が示 唆されているが38)，詳細は不明である。

\section{G6b-B}

血小板膜上には糖鎖の違いで $25 \mathrm{kDa}$ と $28 \mathrm{kDa} の$

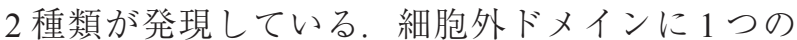
Ig-like domain を持つ。構造を詳しく述べた論文は 無い。細胞内ドメインには 2 つ ITIM motif が存 在し，SHP-1，SHP-2により抑制性のシグナルを惹 起すると考えられる，G6bにはへパリンが結合する が，これが血小板機能に影響を与えているかは不明 である。抗体で G6b-B をクロスリンクすると GPVI 刺激で惹起される血小板凝集反応が減弱することか $ら^{39)}$ ，PECAM-1 と同様の役割を演じていると予想 される. G6b-B 欠損マウスには macrothrombocytopenia と血小板機能低下が観察される ${ }^{40)}$. 同マウ久 の巨核球は metalloproteinase の産生が克進し膜蛋白 が過剩に shedされており, proplatelet formationの 異常も認められる。 G6b-B による抑制性シグナルは 巨核球からの血小板産生に重要である可能性が示唆 さるが，血栓止血メカニズムにおける生体内での役 割は依然不明である。

\section{TLT-1 (triggering receptor expressed on myeloid cells}

\section{(TREM) -like transcript-1)}

細胞外ドメインに 1つの Vセット (Ig-V-like domain)が存在する。 TREMs は好中球やマクロファー ジ，樹状細胞などに発現する活性化受容体で，自然 免疫応答に関与している。血小板膜上の TLT-1 は CD62p と同様に $\alpha$ 顆粒膜表面に発現し，活性化に 伴い血小板膜表面に表出される。細胞内ドメインに 2 つの ITIM motif が存在し, SHP-1 や SHP-2 が結合 して血小板機能の抑制を作用する可能性が考えられ るが，詳細は不明である ${ }^{41,42) . ~}$

\section{DNAM-1 (CD226)}

細胞外ドメインに2つの Vセット (Ig-V-like domain)を持つ $65 \mathrm{kDa}$ の膜蛋白である. 細胞内ドメイン には ITAM motif や ITIM motif は存在しない.NK 細 胞や $\mathrm{T}$ 細胞にも発現し, 細胞傷害機能やサイトカ インの放出に関与している。血小板膜上には 1 血小 板あたり 1200 copy 程度発現している ${ }^{43)}$. DNAM-1 のリガンドはよくわかっていないが，ある種の腫瘍 が発現する Ig-SF の Necl-5 と結合する可能性が報告 されている ${ }^{44)}$. DNAM-1 は巨核球や活性化血小板が 血管内皮細胞へ接着する現象に関わると考えられる が，血管内皮細胞側のリガンドや DNAM-1 下流の 細胞内シグナル伝達メカニズムは不明である。 Mast cell では FceRI と synagistic に機能し, Fyn や LAT, PLC 2 を介した活性化シグナルを惹起している ${ }^{45)}$. 血小板にも FceRI や Fyn, LAT, PLC $\gamma 2$ が発現して おり，同様のシグナル伝達メカニズムが存在する可 能性がある。

\section{Gas6 (growth arrest-specific gene 6) 受容体 (TAM 受 容体)}

Gas6 は protein S と類似した蛋白で, $\gamma$ カルボキ シグルタミン酸(Gla) ドメインを持つ. 血小板 $\alpha$ 顆 粒から放出され ${ }^{46)}$ ，抗血栓作用を示すと報告されて いる ${ }^{47)}$. Gas6 欠損マウスの詳細については, 下田 純一先生の総説に詳しくまとめられている ${ }^{48)}$.

Gas6 受容体は 3 つのグループ, Tyr3 (Rse, Brt, Tif, Dtk, Etk2, Sky), Axl (Ufo, Ark, Tyro7), Mer (c-Eyk, Nyk, Tyro12)が知られており，それぞれの頭文字を とって TAM 受容体と呼ばれる。TAM 受容体は細胞 外ドメインに $2 つ の$ Ig-C2-like domain と, 細胞内ド メインに tyrosine kinase domain を持つ. TAM 受容 
体からの血小板活性化シグナル下流で PI3K が活性 化されることから，インテグリン $\alpha \operatorname{IIb} \beta 3$ の活性化 に関わる可能性がある ${ }^{49)}$.

\section{7. 最後に}

現在, 抗血小板薬として最短距離にいるのは GPVI/FcR $\gamma$ 阻害薬であろう。抗血小板薬には「血小 板凝集は抑えるが出血はしにくい」という相反する 特性が求められる。これまで報告された GPVI 欠損 症患者ではコラーゲン凝集は完全に欠損するものの 重篤な出血傾向は認められていない. GPVI とヒト IgG-Fc 部分の融合蛋白 Ravacept せたマウスに投与すると, 梗塞巣や脳浮腫の減少と 機能回復に良好な結果を得たとの報告がなされてい $ろ^{50)}$.

血小板 Ig-SF には研究が進み治療薬開発段階のも のから詳細不詳のものまで様々あり, 研究開拓が待 たれるフロンティアである。今後の研究発展を期待 したい.

著者の利益相反 (COI)の開示 :

本論文発表内容に関連して開示すべき企業との利益 相反なし

\section{文献}

1) Reth M: Antigen receptor tail clue. Nature 338: 383-384, 1989.

2) Ravetch JV, Lanier LL: Immune inhibitory receptors. Science 290: 84-89, 2000.

3) Clemetson JM, Polgar J, Magnenat E, Wells TN, Clemetson $\mathrm{KJ}$ : The platelet collagen receptor glycoprotein $\mathrm{VI}$ is a member of the immunoglobulin superfamily closely related to FcalphaR and the natural killer receptors. J Biol Chem 274: 29019-29024, 1999.

4) Chen J, Diacovo TG, Grenache DG, Santoro SA, Zutter MM: The alpha(2) integrin subunit-deficient mouse: a multifaceted phenotype including defects of branching morphogenesis and hemostasis. Am J Pathol 161: 337-344, 2002.

5) Best D, Senis YA, Jarvis GE, Eagleton HJ, Roberts DJ, Saito T, Jung SM, Moroi M, Harrison P, Green FR, Watson SP: GPVI levels in platelets: relationship to platelet function at high shear. Blood 102: 2811-2818, 2003.

6) Nieswandt B, Bergmeier W, Schulte V, Rackebrandt K, Gessner JE, Zirngibl H: Expression and function of the mouse collagen receptor glycoprotein VI is strictly dependent on its association with the FcRgamma chain. J Biol Chem 275:
23998-24002, 2000.

7) Kato K, Kanaji T, Russell S, Kunicki TJ, Furihata K, Kanaji S, Marchese P, Reininger A, Ruggeri ZM, Ware J: The contribution of glycoprotein VI to stable platelet adhesion and thrombus formation illustrated by targeted gene deletion. Blood 102: 1701-1707, 2003.

8) Sugiyama T, Okuma M, Ushikubi F, Sensaki S, Kanaji K, Uchino H: A novel platelet aggregating factor found in a patient with defective collagen-induced platelet aggregation and autoimmune thrombocytopenia. Blood 69: 1712-1720, 1987.

9) Moroi M, Jung SM, Okuma M, Shinmyozu K: A patient with platelets deficient in glycoprotein VI that lack both collageninduced aggregation and adhesion. J Clin Invest 84: 14401445, 1989.

10) Arai M, Yamamoto N, Moroi M, Akamatsu N, Fukutake K, Tanoue K: Platelets with $10 \%$ of the normal amount of glycoprotein VI have an impaired response to collagen that results in a mild bleeding tendency. Br J Haematol 89: 124-130, 1995.

11) Ichinohe $T$, Takayama $H$, Ezumi $Y$, Arai M, Yamamoto $N$, Takahashi H, Okuma M: Collagen-stimulated activation of Syk but not c-Src is severely compromised in human platelets lacking membrane glycoprotein VI. J Biol Chem 272: 63-68, 1997.

12) Takahashi H, Moroi M: Antibody against platelet membrane glycoprotein VI in a patient with systemic lupus erythematosus. Am J Hematol 67: 262-267, 2001.

13) Smethurst PA, Joutsi-Korhonen L, O'Connor MN, Wilson E, Jennings NS, Garner SF, Zhang Y, Knight CG, Dafforn TR, Buckle A, IJsseldijk MJ, De Groot PG, Watkins NA, Farndale RW, Ouwehand WH: Identification of the primary collagenbinding surface on human glycoprotein VI by site-directed mutagenesis and by a blocking phage antibody. Blood 103: 903-911, 2004.

14) Dumont B, Minullina I, Loyau S, Monteiro RC, Lacapere JJ, Arocas V, Jandrot-Perrus M: Chimeric Fc receptors identify ligand binding regions in human glycoprotein VI. J Mol Biol 361: 877-887, 2006.

15) Horii K, Kahn ML, Herr AB: Structural basis for platelet collagen responses by the immune-type receptor glycoprotein VI. Blood 108: 936-942, 2006.

16) Chan AC, Iwashima M, Turck CW, Weiss A: ZAP-70: a $70 \mathrm{kd}$ protein-tyrosine kinase that associates with the TCR zeta chain. Cell 71: 649-662, 1992.

17) Watson SP, Asazuma N, Atkinson B, Berlanga O, Best D, Bobe R, Jarvis G, Marshall S, Snell D, Stafford M, Tulasne D, Wilde J, Wonerow P, Frampton J: The role of ITAM- and ITIM-coupled receptors in platelet activation by collagen. Thromb Haemost 86: 276-288, 2001.

18) Kamae T, Shiraga M, Kashiwagi H, Kato H, Tadokoro S, Kurata Y, Tomiyama Y, Kanakura Y: Critical role of ADP interaction with $\mathrm{P} 2 \mathrm{Y} 12$ receptor in the maintenance of alpha(IIb)beta3 activation: association with Rap1B activation. J Thromb Haemost 4: 1379-1387, 2006.

19) Rosenfeld SI, Looney RJ, Leddy JP, Phipps DC, Abraham GN, Anderson CL: Human platelet Fc receptor for immunoglobulin G. Identification as a 40,000-molecular-weight membrane 
protein shared by monocytes. J Clin Invest 76: 2317-2322, 1985.

20) Karas SP, Rosse WF, Kurlander RJ: Characterization of the IgG-Fc receptor on human platelets. Blood 60: 1277-1282, 1982

21) Visentin GP, Ford SE, Scott JP, Aster RH: Antibodies from patients with heparin-induced thrombocytopenia/thrombosis are specific for platelet factor 4 complexed with heparin or bound to endothelial cells. J Clin Invest 93: 81-88, 1994.

22) Gratacap MP, Hérault JP, Viala C, Ragab A, Savi P, Herbert JM, Chap H, Plantavid M, Payrastre B: FcgammaRIIA requires a Gi-dependent pathway for an efficient stimulation of phosphoinositide 3-kinase, calcium mobilization, and platelet aggregation. Blood 96: 3439-3446, 2000.

23) Boylan B, Gao C, Rathore V, Gill JC, Newman DK, Newman PJ: Identification of FcgammaRIIa as the ITAM-bearing receptor mediating alphaIIbbeta3 outside-in integrin signaling in human platelets. Blood 112: 2780-2786, 2008.

24) Zhi H, Rauova L, Hayes V, Gao C, Boylan B, Newman DK, McKenzie SE, Cooley BC, Poncz M, Newman PJ: Cooperative integrin/ITAM signaling in platelets enhances thrombus formation in vitro and in vivo. Blood 121: 1858-1867, 2013.

25) Sobocka MB, Sobocki T, Banerjee P, Weiss C, Rushbrook JI, Norin AJ, Hartwig J, Salifu MO, Markell MS, Babinska A, Ehrlich YH, Kornecki E: Cloning of the human platelet F11 receptor: a cell adhesion molecule member of the immunoglobulin superfamily involved in platelet aggregation. Blood 95: 2600-2609, 2000.

26) Gupta SK, Pillarisetti K, Ohlstein EH: Platelet agonist F11 receptor is a member of the immunoglobulin superfamily and identical with junctional adhesion molecule (JAM): regulation of expression in human endothelial cells and macrophages. IUBMB Life 50: 51-56, 2000.

27) Newman DK, Hamilton C, Newman PJ: Inhibition of antigen-receptor signaling by Platelet Endothelial Cell Adhesion Molecule-1 (CD31) requires functional ITIMs, SHP-2, and p56(lck). Blood 97: 2351-2357, 2001.

28) Dhanjal TS, Ross EA, Auger JM, McCarty OJ, Hughes CE, Senis YA, Buckley CD, Watson SP: Minimal regulation of platelet activity by PECAM-1. Platelets 18: 56-67, 2007.

29) Jackson DE, Kupcho KR, Newman PJ: Characterization of phosphotyrosine binding motifs in the cytoplasmic domain of platelet/endothelial cell adhesion molecule-1 (PECAM-1) that are required for the cellular association and activation of the protein-tyrosine phosphatase, SHP-2. J Biol Chem 272: 24868-24875, 1997.

30) Cicmil M, Thomas JM, Leduc M, Bon C, Gibbins JM: Platelet endothelial cell adhesion molecule-1 signaling inhibits the activation of human platelets. Blood 99: 137-144, 2002.

31) Jones KL, Hughan SC, Dopheide SM, Farndale RW, Jackson SP, Jackson DE: Platelet endothelial cell adhesion molecule-1 is a negative regulator of platelet-collagen interactions. Blood 98: 1456-1463, 2001

32) Rathore V, Stapleton MA, Hillery CA, Montgomery RR, Nichols TC, Merricks EP, Newman DK, Newman PJ: PECAM-1 negatively regulates GPIb/V/IX signaling in murine platelets. Blood 102: 3658-3664, 2003.
33) Tourdot BE, Brenner MK, Keough KC, Holyst T, Newman PJ, Newman DK: Immunoreceptor tyrosine-based inhibitory motif (ITIM)-mediated inhibitory signaling is regulated by sequential phosphorylation mediated by distinct nonreceptor tyrosine kinases: a case study involving PECAM-1. Biochemistry 52: 2597-2608, 2013.

34) Patil S, Newman DK, Newman PJ: Platelet endothelial cell adhesion molecule-1 serves as an inhibitory receptor that modulates platelet responses to collagen. Blood 97: 17271732, 2001.

35) Falati S, Patil S, Gross PL, Stapleton M, Merrill-Skoloff G, Barrett NE, Pixton KL, Weiler H, Cooley B, Newman DK, Newman PJ, Furie BC, Furie B, Gibbins JM: Platelet PECAM1 inhibits thrombus formation in vivo. Blood 107: 535-541, 2006.

36) Wee JL, Jackson DE: The Ig-ITIM superfamily member PECAM-1 regulates the "outside-in" signaling properties of integrin alpha(IIb)beta3 in platelets. Blood 106: 3816-3823, 2005.

37) Joseph M, Gounni AS, Kusnierz JP, Vorng H, Sarfati M, Kinet JP, Tonnel AB, Capron A, Capron M: Expression and functions of the high-affinity $\operatorname{IgE}$ receptor on human platelets and megakaryocyte precursors. Eur J Immunol 27: 2212-2218, 1997.

38) Hasegawa S, Pawankar R, Suzuki K, Nakahata T, Furukawa S, Okumura K, Ra C: Functional expression of the high affinity receptor for IgE (FcepsilonRI) in human platelets and its' intracellular expression in human megakaryocytes. Blood 93: 2543-2551, 1999

39) Newland SA, Macaulay IC, Floto AR, de Vet EC, Ouwehand WH, Watkins NA, Lyons PA, Campbell DR: The novel inhibitory receptor G6B is expressed on the surface of platelets and attenuates platelet function in vitro. Blood 109: 4806-4809, 2007.

40) Mazharian A, Wang YJ, Mori J, Bem D, Finney B, Heising S, Gissen P, White JG, Berndt MC, Gardiner EE, Nieswandt B, Douglas MR, Campbell RD, Watson SP, Senis YA: Mice lacking the ITIM-containing receptor G6b-B exhibit macrothrombocytopenia and aberrant platelet function. Sci Signal 5: ra78, 2012.

41) Barrow AD, Astoul E, Floto A, Brooke G, Relou IA, Jennings NS, Smith KG, Ouwehand W, Farndale RW, Alexander DR, Trowsdale J: Cutting edge: TREM-like transcript-1, a platelet immunoreceptor tyrosine-based inhibition motif encoding costimulatory immunoreceptor that enhances, rather than inhibits, calcium signaling via SHP-2. J Immunol 172: 5838-5842, 2004.

42) Washington AV, Schubert RL, Quigley L, Disipio T, Feltz R, Cho EH, McVicar DW: A TREM family member, TLT-1, is found exclusively in the alpha-granules of megakaryocytes and platelets. Blood 104: 1042-1047, 2004.

43) Scott JL, Dunn SM, Jin B, Hillam AJ, Walton S, Berndt MC, Murray AW, Krissansen GW, Burns GF: Characterization of a novel membrane glycoprotein involved in platelet activation. J Biol Chem 264: 13475-13482, 1989.

44) Morimoto K, Satoh-Yamaguchi K, Hamaguchi A, Inoue Y, Takeuchi M, Okada M, Ikeda W, Takai Y, Imai T: Interaction 
of cancer cells with platelets mediated by Necl-5/poliovirus receptor enhances cancer cell metastasis to the lungs. Oncogene 27: 264-273, 2008.

45) Bachelet I, Munitz A, Mankutad D, Levi-Schaffer F: Mast cell costimulation by CD226/CD112 (DNAM-1/Nectin-2): a novel interface in the allergic process. J Biol Chem 281: 27190 27196, 2006.

46) Ishimoto $Y$, Nakano $T$ : Release of a product of growth arrestspecific gene 6 from rat platelets. FEBS Lett 466: 197-199, 2000.

47) Gould WR, Baxi SM, Schroeder R, Peng YW, Leadley RJ, Peterson JT, Perrin LA: Gas6 receptors Axl, Sky and Mer enhance platelet activation and regulate thrombotic responses. J
Thromb Haemost 3: 733-741, 2005.

48）下田純一，濱本高義：Gas 6 の欠損マウス. 血栓止血誌 12: 514-521, 2001.

49) Cosemans JM, Van Kruchten R, Olieslagers S, Schurgers LJ, Verheyen FK, Munnix IC, Waltenberger J, Angelillo-Scherrer A, Hoylaerts MF, Carmeliet P, Heemskerk JW: Potentiating role of Gas6 and Tyro3, Axl and Mer (TAM) receptors in human and murine platelet activation and thrombus stabilization. J Thromb Haemost 8: 1797-808, 2010.

50) Goebel S, Li Z, Vogelmann J, Holthoff HP, Degen H, Hermann DM, Gawaz M, Ungerer M, Münch G. The GPVIFc fusion protein Revacept improves cerebral infarct volume and functional outcome in stroke. PLoS One 8: e66960, 2013. 